\title{
Peran Pembangunan Infrastruktur terhadap Ketimpangan Ekonomi Antarwilayah di Indonesia
}

\author{
Tatan Sukwika \\ Universitas Sahid Jakarta, Jakarta, Indonesia
}

Artikel Masuk : 26 Februari 2018

Artikel Diterima : 25 Juli 2018

Tersedia Online : 31 Agustus 2018

\begin{abstract}
Abstrak: Kesenjangan infrastruktur antarwilayah dianggap sebagai salah satu faktor yang mendorong terjadinya ketimpangan ekonomi antarwilayah. Dalam konteks Indonesia, isu tersebut menarik untuk dikaji, terlebih pemerintah saat ini tengah gencar mendorong pembangunan infrastrutur di berbagai wilayah di Indonesia. Studi ini bertujuan untuk menganalisis dinamika ketimpangan infrastruktur dan ekonomi antarwilayah (provinsi) di Indonesia serta mengkaji keterkaitan di antara keduanya. Penelitian ini menggunakan beberapa metode yaitu Indeks Williamson, tipologi Klassen, analisis korelasi dan regresi. Metode ini diharapkan dapat memberikan lingkup analisis yang memadai untuk menginvestigasi tren dan keterkaitan pembangunan infrastruktur dan ketimpangan ekonomi antara wilayah di Indonesia. Hasil penelitian menemukan adanya kesenjangan ekonomi (PDRB per kapita) yang cukup tinggi antarprovinsi di Indonesia selama periode 2011-2015. Hal ini diperlihatkan oleh nilai Indeks Williamson PDRB per kapita yang berkisar pada angka 0.7. Tingginya kesenjangan tersebut seringkali diasosiasikan dengan kesenjangan infrastruktur yang terjadi di antara provinsi. Hasil ini terlihat dari cukup kuatnya korelasi positif antara kesenjangan PDRB per kapita dan kesenjangan infrastruktur antarprovinsi. Temuan ini merupakan pesan kuat bagi pemerintah untuk perlu mengakslerasi program-program pemerataan pembangunan secara proposional terutama di wilayah yang dianggap masih tertinggal sehingga proses pembangunan infrastruktur tidak bias wilayah yang sudah maju.
\end{abstract}

Kata Kunci: infrastruktur; Indeks Williamson; ketimpangan wilayah; tipologi Klassen

\begin{abstract}
Infrastructure disparity is considered as one of the factors that enhances economic inequality between regions. In the Indonesian context, the issue is interesting to be examined, especially the government is currently encouraging infrastructure development in various regions in Indonesia. This study aims at analyzing the dynamics of infrastructure and economic inequalities between regions (provinces) in Indonesia and examining the relationship between the two. This research employs several methods, namely Williamson Index, Klassen typology, and correlation and regression analyses. These methods are to provide an adequate scope of analysis to investigate trends and linkages of infrastructure development and economic imbalances between provinces in Indonesia. The study results find that the economic gap (in term of GRDP per capita) among the provinces in Indonesia was relatively high during the period 2011-2015. It was confirmed by the value of Williamson Index at 0.7 points. The relatively high rate of the gap was mostly associated with the infrastructure gap among the provinces. Strong positive correlation between the gap of GRDP per capita and of infrastructure
\end{abstract}

Korespondensi Penulis: Universitas Sahid Jakarta, Jakarta, Indonesia

Email: tatan.swk@gmail.com 


\section{Peran Pembangunan Infrastruktur terhadap Ketimpangan Ekonomi Antarwilayah di Indonesia}

among provinces. This delivers a strong message to the government to accelerate equal development programs proportionally in lagging regions in order to reduce development bias to more developed regions.

Keywords: infrastructure; Klassen typology; regional inequality; Williamson Index

\section{Pendahuluan}

Pertumbuhan ekonomi merupakan salah satu indikator untuk mengukur kinerja ekonomi suatu negara. Negara akan mengalami kesulitan untuk meningkatkan standar hidup masyarakat tanpa adanya pertumbuhan yang positif. Di sisi lain, pertumbuhan ekonomi tidak senantiasa menjamin terciptanya keadilan dan kesejahteraan sosial dalam masyarakat. Pembangunan yang hanya mengejar pertumbuhan ekonomi semata berpotensi melahirkan ketidakadilan yang berujung pada ketimpangan dalam kehidupan bermasyarakat. Dengan demikian, pertumbuhan ekonomi dengan sendirinya tidak dapat dianggap sebagai tujuan akhir pembangunan.

Salah satu tantangan utama pembangunan Indonesia saat ini adalah mengatasi persoalan ketimpangan yang tidak hanya terjadi dalam dimensi individu atau rumah tangga tetapi juga wilayah. Data Badan Pusat Statistik (BPS) menunjukkan selama lebih dari tiga dekade terakhir, rata-rata laju pertumbuhan ekonomi Indonesia relatif tinggi, namun pada saat yang bersamaan tingkat kesenjangan pendapatan juga tinggi. Data kemiskinan selama 1970-2017 menunjukkan bahwa rata-rata tingkat kemiskinan di kawasan perkotaan adalah 13,9 persen, sedangkan di kawasan perdesaan mencapai 19,0 persen (BPS, 2018). Kondisi tersebut menunjukkan bahwa kemiskinan paling banyak dialami penduduk perdesaan yang umumnya bekerja di sektor pertanian. Selain kemiskinan dalam dimensi desa-kota (Chotia \& Rao, 2017; Madhu Sehrawat, 2016; Østby, 2016), ketimpangan juga terjadi pada dimensi wilayah lainnya, seperti antara kawasan barat-timur dan kawasan Jawa-Luar Jawa (Bhinadi, 2003; Hermayeni, Ekwarso, \& Tampubolon, 2015; Yuliadi, 2012). Investasi publik menghasilkan korelasi positif antara pertumbuhan dan ketimpangan pendapatan (Charlery, Qaim, \& Smith-Hall, 2016; Chatterjee \& Turnovsky, 2012), namun demikian pembangunan infrastruktur yang tidak seimbang dapat menyebabkan kegagalan terhadap pengurangan ketimpangan pertumbuhan ekonomi (Chotia \& Rao, 2017), karena kondisi kesenjangan antardaerah terjadi sebagai konsekuensi dari pembangunan yang terkonsentrasi pada wilayah-wilayah tertentu saja.

Sejumlah literatur menyebutkan bahwa terdapat beberapa faktor yang mendorong perubahan ketimpangan di Indonesia, salah satunya adalah perbedaan pembangunan infrastruktur antarwilayah. Sebagai roda penggerak pertumbuhan ekonomi, infrastruktur berperan signifikan dalam pengembangan wilayah. Beberapa fakta empiris menunjukkan bahwa perkembangan kapasitas infrastruktur di suatu wilayah berjalan seiring dengan perkembangan ekonominya (Calderón \& Servén, 2004; Démurger, 2001; Maryaningsih, Hermansyah, \& Savitri, 2014). Hal ini karena perkembangan ekonomi telah menuntut ketersediaan sarana dan prasarana infrastruktur yang memadai. Keberadaan infrastruktur mendorong peningkatan produktivitas faktor-faktor produksi. Perbaikan infrastruktur meningkatkan investasi dan pertumbuhan ekonomi, karena investasi akan meningkatkan penyerapan tenaga kerja. Menurut Siregar \& Sukwika (2007), investasi memainkan peranan penting dalam menentukan penyerapan tenaga kerja. Infrastruktur yang baik juga akan merangsang peningkatan pendapatan masyarakat, karena aktivitas ekonomi yang semakin meningkat sebagai akibat mobilitas faktor produksi dan aktivitas perdagangan yang semakin tinggi. Dengan demikian, perkembangan infrastruktur dengan pembangunan ekonomi memiliki hubungan yang sangat erat dan saling tergantung satu sama lain. Ketimpangan pembangunan infrastruktur yang terjadi juga akan berperan terhadap kesenjangan pembangunan ekonomi yang berujung pada ketimpangan kesejahteraan antarwilayah 
(Démurger, 2001; Fan \& Chan-Kang, 2008; Surd, Kassai, \& Giurgiu, 2011; Warr, Menon, \& Rasphone, 2015).

Berdasarkan kondisi tersebut, kajian mengenai keterkaitan/dampak kesenjangan pembangunan infrastruktur terhadap ketimpangan di Indonesia, baik ketimpangan individu/rumah tangga dan ketimpangan wilayah menjadi menarik dan strategis untuk dikaji, karena hal ini dapat memberikan masukan dan informasi yang memadai bagi pembuat kebijakan dalam merumuskan kebijakan untuk mengakselerasi pengurangan kesenjangan pembangunan infrastruktur antarwilayah dalam upaya mewujudkan keadilan dan pemerataan pembangunan bagi seluruh masyarakat Indonesia. Kajian ini bertujuan untuk (1) mendeskripsikan dinamika terkini kesenjangan (disparitas) infrastruktur dan kesenjangan sosial-ekonomi antarwilayah di Indonesia; (2) mengukur dan menganalisis tren indeks ketimpangan infrastruktur dan indeks ketimpangan sosial-ekonomi antarwilayah di Indonesia; dan (3) menganalisis keterkaitan/dampak kesenjangan infrastruktur terhadap kesenjangan sosial-ekonomi di Indonesia.

Kajian mengenai peran pembangunan infrastruktur terhadap pertumbuhan ekonomi dan ketimpangan ekonomi antarwilayah dalam konteks Indonesia telah dilakukan dalam beberapa studi empiris sebelumnya. Studi Muljono, Antameng, Sinaga, \& Daryanto (2010) mengkaji dampak pembangunan jalan pada pendapatan faktor produksi, baik untuk intra dan antarwilayah barat-timur Indonesia. Studi ini menemukan bahwa dampak pembangunan jalan dapat meningkatkan pendapatan faktor produksi, namun dampak tersebut berbeda antarwilayah. Hal tersebut menunjukkan bahwa kawasan perkotaan mendapatkan manfaat pendapatan dari faktor produksi yang lebih besar daripada kawasan perdesaan. Selain itu, secara antarwilayah, Kawasan Barat Indonesia (KBI) mendapat manfaat yang lebih besar dibandingkan dengan Kawasan Timur Indonesia (KTI). Selanjutnya, studi Maryaningsih et al. (2014) menemukan bahwa kondisi infrastruktur jalan dan listrik berdampak signifikan terhadap pertumbuhan pendapatan per kapita, namun tidak demikian dengan pelabuhan. Fahmi (2015) mengkaji pengaruh infrastruktur dan keterkaitan spasial terhadap konvergensi beta di Indonesia. Studi ini menemukan bahwa infrastruktur jalan berpengaruh positif terhadap pertumbuhan ekonomi dan secara spasial investasi dan infrastruktur jalan juga menunjukkan pengaruh positif terhadap pertumbuhan ekonomi. Melalui kondisi tersebut, investasi dan infrastruktur jalan suatu wilayah tidak hanya berpengaruh terhadap pertumbuhan ekonomi wilayah tersebut tetapi juga terhadap perekonomian wilayah di sekitarnya. Dalam konteks provinsi, Sumadiasa, Trisnawati, \& Wirathi (2016) mengkaji pembangunan infrastruktur jalan, listrik, dan penanaman modal asing (PMA) terhadap pertumbuhan Produk Domestik Regional Bruto (PDRB) Provinsi Bali. Studi ini menemukan bahwa pembangunan jalan berpengaruh positif namun tidak signifikan terhadap pertumbuhan PDRB, sedangkan listrik memiliki pengaruh positif dan signifikan terhadap pertumbuhan PDRB.

Berbeda dengan studi empiris terdahulu yang lebih banyak mengulas peran infrastruktur terhadap perekonomian wilayah, studi ini fokus pada bagaimana peran infrastruktur terhadap ketimpangan antarwilayah. Dalam konteks Indonesia, topik ini masih cukup terbatas. Kelebihan lain studi ini adalah penggunaan data infrastruktur yang lebih luas, meliputi jalan, air bersih, dan irigasi. Dengan demikian, hasil studi ini diharapkan dapat melengkapi studi-studi yang berkaitan dengan peran infrastruktur terhadap perekonomian wilayah.

\section{Metode Penelitian}

\section{Pengukuran Ketimpangan Wilayah}

Ketimpangan pembangunan antarwilayah diukur dengan Indeks Williamson. Indeks ini menggunakan PDRB per kapita (Williamson, 1965). Semakin tinggi nilai Indeks 
Williamson, berarti kesenjangan ekonomi antarwilayah semakin besar, dan sebaliknya. Indeks Williamson diformulasikan dalam persamaan (1) sebagai berikut.

$$
C V w=\frac{\sqrt{\sum_{I}(Y i-\bar{Y})^{2} \cdot \frac{f i}{f}}}{\bar{Y}}
$$

Keterangan:

$\mathrm{CVw} \quad$ : Indeks Williamson

fi : Jumlah penduduk di wilayah yuridis ke-i yang lebih rendah (kabupaten/kota atau provinsi) (jiwa)

$f \quad$ : Jumlah penduduk seluruh wilayah yuridis yang lebih tinggi (provinsi atau nasional) (jiwa)

$Y_{i} \quad$ : PDRB per kapita di wilayah yuridis ke-i yang lebih rendah (kabupaten/kota atau provinsi) (rupiah)

$Y \quad$ : PDRB per kapita rata-rata seluruh wilayah yuridis yang lebih tinggi (provinsi atau nasional) (rupiah)

\section{Tipologi Klassen}

Analisis Tipologi Klassen digunakan untuk mengukur pertumbuhan ekonomi daerah dan pendapatan per kapita daerah berdasarkan empat karakteristik pola dan struktur pertumbuhan ekonomi yang berbeda, yaitu daerah cepat-maju dan cepat-tumbuh (high growth and high income), daerah maju tapi tertekan (high income but low growth), daerah berkembang cepat (high growth but low income), dan daerah relatif tertinggal (low growth and low income) (Aswandi \& Kuncoro, 2002). Tabel 1 menunjukkan Tipologi Klassen untuk suatu indikator pembangunan ekonomi yang diklasifikasikan ke dalam empat kuadran karakteristik.

Tabel 1. Klasifikasi Pertumbuhan PDRB Per Kapita Berdasarkan Tipologi Klassen

\begin{tabular}{cll}
\hline Paju Pertumbuhan (r) & \multicolumn{1}{c}{$\mathbf{Y}_{\mathbf{d i}}>\mathbf{y d i}$} & \multicolumn{1}{c}{$\mathbf{Y}_{\mathbf{d i}}<\mathbf{y}_{\mathbf{d i}}$} \\
\hline $\mathrm{R}_{\mathrm{di}}>\mathrm{r}_{\mathrm{ni}}$ & $\begin{array}{l}\text { Daerah lebih maju dan cepat } \\
\text { tumbuh (Kuadran I) }\end{array}$ & $\begin{array}{l}\text { Daerah belum maju tetapi } \\
\text { berkembang cepat } \\
\text { (Kuadran II) }\end{array}$ \\
\cline { 2 - 3 } $\mathrm{R}_{\mathrm{di}}<\mathrm{r}_{\mathrm{ni}}$ & $\begin{array}{l}\text { Daerah lebih maju tetapi tertekan } \\
\text { (Kuadran IV) }\end{array}$ & $\begin{array}{l}\text { Daerah relatif lebih } \\
\text { tertinggal (Kuadran III) }\end{array}$ \\
\hline
\end{tabular}

Sumber: Analisis Penulis, 2018

Keterangan:

$\mathrm{r}_{\mathrm{ni}} \quad$ : rata-rata laju PDRB per kapita provinsi

$\mathrm{R}_{\mathrm{di}}$ : rata-rata laju PDRB per kapita provinsi secara nasional

$\mathrm{y}_{\mathrm{di}}$ : rata-rata PDRB per kapita provinsi

$\mathrm{Y}_{\mathrm{di}}$ : rata-rata PDRB per kapita provinsi secara nasional

\section{Pengukuran Keterkaitan Kesenjangan Infrastruktur dan Ketimpangan Ekonomi Antanwilayah}

Analisis keterkaitan disparitas pembangunan infrastruktur dengan ketimpangan ekonomi antarwilayah akan dilakukan dengan menggunakan analisis korelasi linier Pearson. Formulasi pengukuran koefisien korelasi Pearson tersebut dapat dilihat pada persamaan (2), 


$$
r=\frac{\sum(X-\bar{X})(Y-\bar{Y})}{(n-1) S_{X} S_{Y}}
$$

dengan $r$ adalah koefisien korelasi yang nilainya terletak di antara -1 dan 1. $X$ dan $Y$ adalah dua variabel yang akan diukur korelasinya, dan $n$ menyatakan jumlah sampel yang digunakan, persamaan ini dapat dilihat pada persamaan (3).

$$
S_{x}=\sqrt{\frac{\sum_{i=1}^{n}\left(X_{i}-\bar{X}\right)^{2}}{n-1}} \text { dan } S_{y}=\sqrt{\frac{\sum_{i=1}^{n}\left(Y_{i}-\bar{Y}\right)^{2}}{n-1}}
$$

Berdasarkan persamaan (2) dapat diidentifikasi bahwa jika koefisien $r$ bernilai positif dan cenderung mendekati 1, maka mengindikasikan adanya korelasi positif di antara kedua variabel yang dianalisis. Hal tersebut menunjukkan bahwa meningkatnya ketimpangan ekonomi antarwilayah dapat diasosiasikan dengan meningkatnya kesenjangan infrastruktur yang terjadi di antara wilayah tersebut. Sebaliknya, koefisien korelasi yang cenderung mendekati -1 menjelaskan kondisi yang berlawanan. Naiknya ketimpangan ekonomi antarwilayah diasosiasikan dengan menurunnya ketimpangan infrastruktur di antara wilayah tersebut. Sementara itu, koefisien korelasi yang mendekati 0 menjelaskan tidak adanya keterkaitan antara ketimpangan ekonomi antarwilayah dan tingkat kesenjangan infrastruktur di antara wilayah tersebut.

\section{Hasil dan Pembahasan}

\section{Analisis Kesenjangan Ekonomi Antarprovinsi Indonesia}

Indeks Williamson dan coefficient variation (CV) merupakan salah satu cara yang dapat digunakan untuk mengukur kesenjangan ekonomi antarprovinsi di Indonesia. Pada Indeks Williamson, jika angka indeks mendekati angka nol, maka tingkat ketimpangan semakin kecil. Sebaliknya, jika angka indeks mendekati angka satu, maka tingkat ketimpangan semakin tinggi. Hasil perhitungan selama kurun waktu 2010-2015 memperlihatkan bahwa Indeks Williamson dan nilai CV dari PDRB per kapita provinsi di Indonesia menunjukkan dua pergerakan yang sedikit berbeda (lihat Gambar 1a). Nilai CV konsisten menunjukkan penurunan selama periode tersebut, sedangkan nilai Indeks Williamson menunjukan dua fase yang berbeda. Pada periode 2010-2012, nilai Indeks Williamson cenderung meningkat, dan pada periode 2013-2015 cenderung menurun. Hasil ini menunjukkan bahwa tren terkini ketimpangan antarprovinsi di Indonesia cenderung membaik meskipun nilai Indeks Williamson berkisar pada angka 0,7 masih tergolong cukup tinggi. Fakta ini menyarankan kepada pemerintah untuk mengakselerasi program-program pemerataan pembangunan di seluruh wilayah. Dengan demikian, proses pembangunan yang terjadi tidak hanya bias pada wilayah yang sudah maju saja, tetapi juga pada wilayah-wilayah lainnya yang dianggap masih tertinggal.

Tabel 2 memperlihatkan bahwa provinsi di Indonesia dapat diklasifikasikan menjadi empat kriteria berdasarkan tipologi Klassen. Kriteria pertama adalah daerah lebih maju (dengan tingkat PDRB per kapita di atas rata-rata provinsi secara nasional) dan memiliki pertumbuhan lebih cepat (dengan tingkat pertumbuhan PDRB per kapita di atas rata-rata provinsi secara nasional), yang dikategorikan dalam Kuadran I. Kriteria kedua adalah daerah relatif belum maju (dengan tingkat PDRB per kapita di bawah rata-rata provinsi secara nasional), namun memiliki tingkat pertumbuhan PDRB per kapita di atas rata-rata provinsi secara nasional, yang dikategorikan dalam Kuadran II. Kriteria ketiga adalah daerah relatif 


\section{Peran Pembangunan Infrastruktur terhadap Ketimpangan Ekonomi Antarwilayah di Indonesia}

tertinggal karena memiliki tingkat PDRB per kapita dan tingkat pertumbuhan di bawah ratarata provinsi secara nasional, yang dikategorikan dalam Kuadran III. Kriteria terakhir adalah daerah maju (dengan tingkat PDRB per kapita di atas rata-rata PDRB provinsi secara nasional) tetapi dianggap tertekan karena memiliki tingkat pertumbuhan PDRB per kapita di bawah rata-rata provinsi secara nasional, yang dikategorikan dalam Kuadran IV. Pembagian kriteria-kriteria tersebut didasarkan pada nilai rata-rata pertumbuhan PDRB per kapita, yang direpresentasikan melalui garis vertikal, dan rata-rata PDRB per kapita yang direpresentasikan melalui garis horizontal. Masing-masing nilai rata-rata tersebut berturutturut adalah 4,07 persen dan Rp 33.690.000 per kapita per tahun.

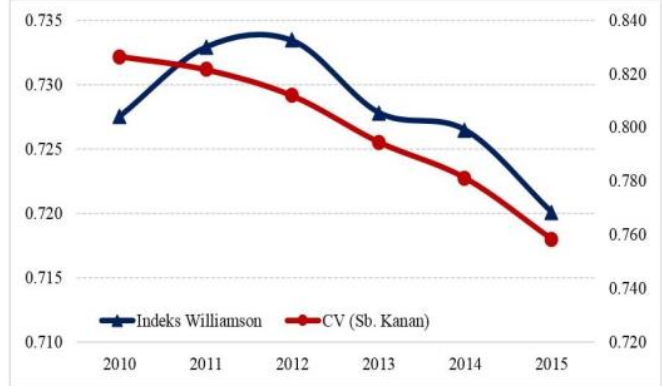

(a)

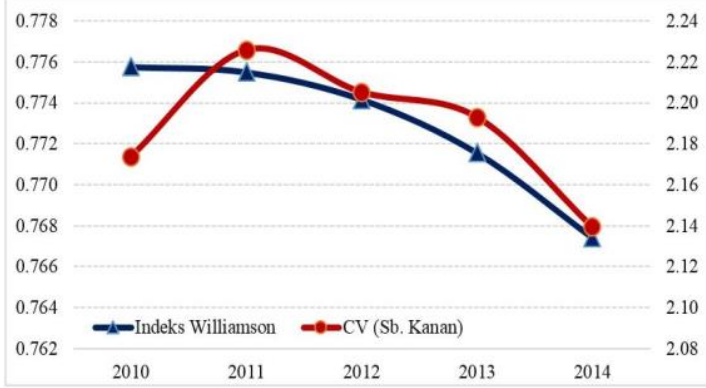

(b)

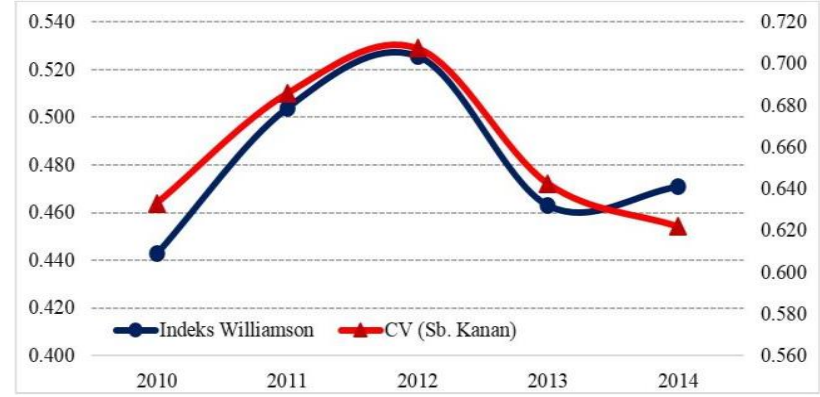

(c)

Keterangan:

(a) CV dan Indeks Williamson PDRB Per Kapita Menurut Provinsi

(b) CV dan Indeks Williamson Panjang Jalan Menurut Provinsi

(c) CV dan Indeks Williamson Jumlah Pelanggan Air Bersih Menurut Provinsi

Sumber: Analisis Penulis, 2018

Gambar 1. CV dan Indeks Williamson PDRB dan Infrastruktur Menurut Provinsi

Tabel 2. Klasifikasi Pertumbuhan PDRB Per Kapita Provinsi di Indonesia Periode 2010-2015 Menurut Tipologi Klassen

\begin{tabular}{|c|c|c|}
\hline $\begin{array}{l}\text { PDRB Per Kapita } \\
\text { Pertumbuhan } \\
\text { (r) }\end{array}$ & $\mathbf{Y}_{\mathbf{d i}}>\mathbf{y}_{\mathbf{d i}}$ & $Y_{d i}<y_{d i}$ \\
\hline $\mathbf{R}_{\mathrm{di}}>\mathbf{r}_{\mathbf{n i}}$ & $\begin{array}{l}\text { Daerah lebih maju dan } \\
\text { cepat tumbuh (Kuadran I) } \\
\text { DKI Jakarta }\end{array}$ & $\begin{array}{l}\text { Daerah belum maju tetapi berkembang cepat } \\
\text { (Kuadran II) } \\
\text { Sumatera Utara, Sumatera Barat } \\
\text { Jambi, Sumatera Selatan, Bengkulu, Lampung, } \\
\text { Jawa Barat, Jawa Tengah, }\end{array}$ \\
\hline
\end{tabular}




\begin{tabular}{ll} 
Laju \\
$\begin{array}{l}\text { Pertumbuhan } \\
\text { (r) }\end{array}$ \\
\hline
\end{tabular}

Daerah Istimewa Yogyakarta, Jawa Timur, Bali, Nusa Tenggara Barat, Kalimantan Barat, Kalimantan Tengah. Sulawesi Utara, Sulawesi Tengah, Sulawesi Selatan, Sulawesi Tenggara, Gorontalo, Sulawesi Barat

\begin{tabular}{lll}
\hline & Daerah lebih maju tetapi & Daerah relatif lebih tertinggal (Kuadran III) \\
tertekan (Kuadran IV) & Nanggroe Aceh Darussalam, Bangka Belitung, \\
$\mathbf{R}_{\mathrm{di}}<\mathbf{r}_{\mathbf{n i}}$ & Riau, Kepulauan Riau, & Banten, Nusa Tenggara Timur, \\
& Kalimantan Timur, Papua & Kalimantan Selatan, Maluku, \\
& Barat, Papua & Maluku Utara \\
\hline
\end{tabular}

Sumber: Analisis Penulis, 2018

Selanjutnya dapat dilihat bahwa provinsi di Indonesia cenderung berada pada Kuadran II dan Kuadran III (Gambar 2). Dalam jangka panjang, provinsi yang terdapat pada Kuadran II diperkirakan akan memberikan dampak positif bagi pertumbuhan PDRB per kapita nasional karena akan mampu mengejar pertumbuhan PDRB per kapita provinsi-provinsi yang sudah maju (memiliki tingkat PDRB per kapita lebih tinggi dari rata-rata provinsi secara nasional) seperti yang terdapat pada Kuadran I. Provinsi yang terdapat pada Kuadran III, yaitu daerah relatif lebih tertinggal, jika tidak mengalami perubahan secara signifikan, diperkirakan akan berdampak negatif bagi pertumbuhan PDRB per kapita nasional karena akan menghambat pertumbuhan dan meningkatkan kesenjangan ekonomi di antara provinsi di Indonesia. Sementara itu, provinsi yang terdapat pada Kuadran IV dianggap sebagai provinsi yang jenuh, karena meskipun memiliki tingkat PDRB per kapita yang relatif tinggi, namun pertumbuhannya cenderung lambat.

Hasil kategorisasi berdasarkan tipologi Klassen (Tabel 2) memperlihatkan bahwa kesenjangan pendapatan (PDRB per kapita) antarprovinsi di Indonesia masih relatif tinggi. Namun demikian, kesenjangan tersebut diperkirakan akan cenderung menurun pada masa mendatang, atau mengalami konvergensi. Fakta ini ditunjukkan oleh garis regresi atau garis tren yang memiliki slope negatif, yang menunjukkan bahwa adanya korelasi negatif antara tingkat PDRB per kapita dan pertumbuhan PDRB per kapita di provinsi di Indonesia. Konvergensi ini diperkirakan terjadi karena provinsi-provinsi yang saat ini memiliki tingkat PDRB per kapita relatif rendah (di bawah rata-rata provinsi secara nasional) memiliki kecenderungan untuk tumbuh lebih cepat. Sebaliknya, provinsi-provinsi yang saat ini memiliki tingkat PDRB per kapita relatif tinggi (di atas rata-rata provinsi secara nasional) memiliki kecenderungan untuk tumbuh lebih lambat. 


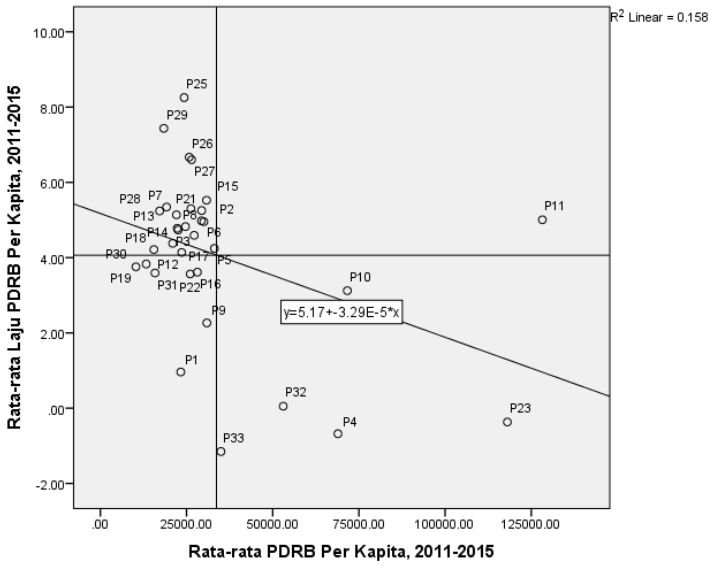

(a)

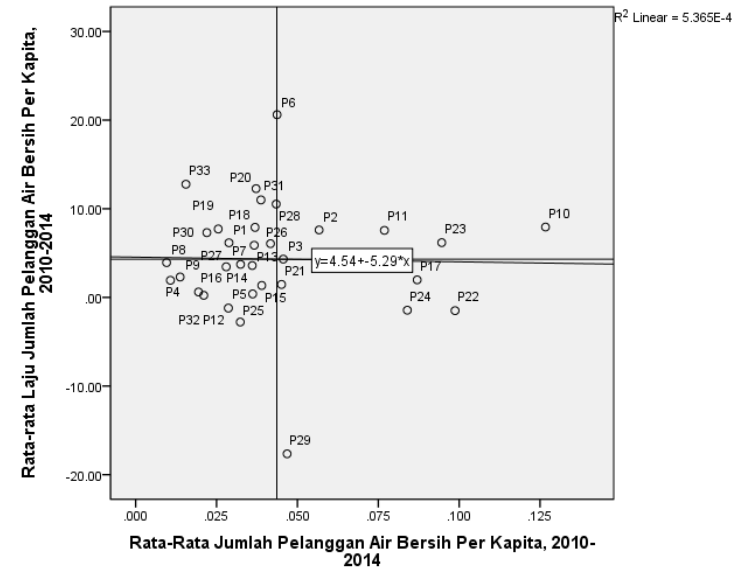

(c)

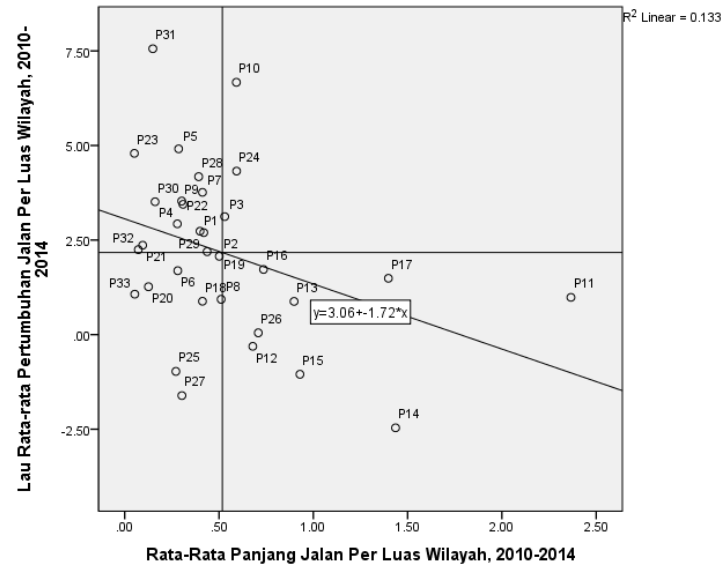

(b)

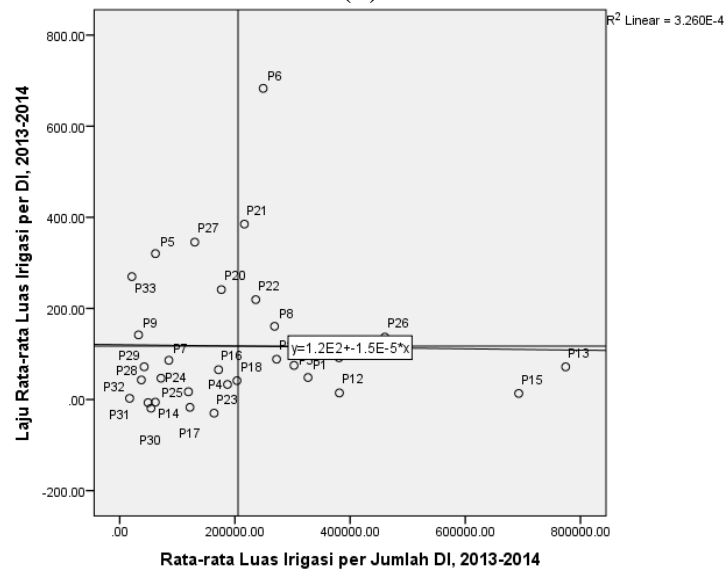

(d)

(a) Perkembangan Ekonomi Provinsi Menurut Tipologi Klassen

(b) Perkembangan Panjang Jalan Provinsi Menurut Tipologi Klassen

(c) Perkembangan Jumlah Pelanggan Air Bersih Menurut Tipologi Klassen

(d) Perkembangan Luas Irigasi Menurut Tipologi Klassen

Keterangan:

\begin{tabular}{|c|c|c|c|c|c|}
\hline P1 & Nanggroe Aceh D. & P12 & Jawa Barat & P23 & Kalimantan Timur \\
\hline $\mathrm{P} 2$ & Sumatera Utara & $\mathrm{P} 13$ & Jawa Tengah & P24 & Sulawesi Utara \\
\hline P3 & Sumatera Barat & P14 & DI Yogyakarta & P25 & Sulawesi Tengah \\
\hline P4 & Riau & P15 & Jawa Timur & P26 & Sulawesi Selatan \\
\hline P5 & Jambi & P16 & Banten & P27 & Sulawesi Tenggara \\
\hline P6 & Sumatera Selatan & $\mathrm{P} 17$ & Bali & P28 & Gorontalo \\
\hline P7 & Bengkulu & P18 & Nusa Tenggara Barat & P29 & Sulawesi Barat \\
\hline P8 & Lampung & P19 & Nusa Tenggara Timur & P30 & Maluku \\
\hline P9 & Bangka Belitung & P20 & Kalimantan Barat & P31 & Maluku Utara \\
\hline P10 & Kepulauan Riau & P21 & Kalimantan Tengah & P32 & Papua Barat \\
\hline P11 & DKI Jakarta & P22 & Kalimantan Selatan & P33 & Papua \\
\hline
\end{tabular}

Sumber: Analisis Penulis, 2018

\section{Gambar 2. Perkembangan PDRB dan Infrastruktur Menurut Tipologi Klassen}

\section{Analisis Kesenjangan Infrastruktur Antarprovinsi Indonesia}

Terdapat beberapa faktor yang disinyalir menyebabkan terjadinya kesenjangan ekonomi (PDRB per kapita) antarprovinsi di Indonesia. Beberapa faktor tersebut di antaranya perbedaan penyerapan investasi serta kesenjangan infrastruktur yang ada. Hal tersebut 
dapat dipahami karena investasi memiliki peranan strategis dalam mendorong pertumbuhan ekonomi daerah. Secara khusus, investasi juga berperan dalam penyerapan tenaga kerja, karena dengan adanya investasi, baik domestik maupun asing, akan meningkatkan kegiatan ekonomi di sektor riil (Rosmeli, 2015; Siregar \& Sukwika, 2007). Hal ini tentunya akan memberikan potensi besar bagi penyerapan tenaga kerja dan pengurangan pengangguran melalui pembukaan lapangan kerja baru. Selain investasi dalam arti luas, ketersediaan infrastruktur juga memegang peranan penting dan strategis sebagai lokomotif pembangunan daerah dan nasional dalam menggerakkan roda pertumbuhan ekonomi daerah. Dalam hal ini, infrastruktur dapat berperan dalam mempermudah proses produksi, distribusi dan pemasaran, serta meningkatkan aktivitas perekonomian daerah secara keseluruhan. Gibson \& Rioja (2014) menyatakan bahwa ketika infrastruktur mempengaruhi ekonomi melalui utilitas dan fungsi produksi, maka peningkatan investasi infrastruktur secara signifikan dapat meningkatkan pertumbuhan dan mengurangi ketimpangan pendapatan, yang menyebabkan kenaikan tajam tingkat pendapatan yang dimiliki oleh wilayah miskin. Hasil penelitian Majumder (2012) menunjukkan bahwa infrastruktur yang memadai dapat meningkatkan standar hidup rata-rata dan menurunkan angka kemiskinan. Selain itu, fasilitas infrastruktur dapat memainkan peran penting dalam pengembangan wilayah (Kateja \& Maurya, 2011). Namun, ketika aspek peningkatan utilitas infrastruktur diabaikan, maka akan berpengaruh pada efek pertumbuhan menjadi lebih kecil dan efek distribusinya hampir tidak ada (Gibson \& Rioja, 2014). Dalam konteks ini, adanya ketimpangan investasi dan infrastruktur akan berperan terhadap ketimpangan ekonomi (PDRB per kapita) antarwilayah di Indonesia.

Studi ini secara khusus mengulas kesenjangan infrastruktur antarprovinsi di Indonesia selama periode 2010-2014. Tujuannya selain untuk melihat bagaimana kesenjangan tersebut terjadi di antara provinsi di Indonesia, juga untuk mengetahui apakah terdapat keterkaitan antara kesenjangan infrastruktur dan kesenjangan ekonomi yang terjadi antarprovinsi selama periode tersebut. Untuk itu, bagian ini secara khusus menganalisis dinamika ketimpangan infrastruktur antarprovinsi di Indonesia yang meliputi panjang jalan, (jumlah pelanggan) air bersih, dan luas irigasi. Namun demikian, karena ketersediaan data, analisis untuk infrastruktur luas irigasi hanya dianalisis selama periode 2013-2014. Berdasarkan Gambar 1b dan Gambar 1c, terdapat kesenjangan infrastruktur di Indonesia seperti panjang jalan, jumlah pelanggan air bersih, dan luas irigasi air cukup bervariasi. Namun demikian, kecuali pada luas irigasi, terdapat kecenderungan bahwa nilai Indeks Williamson dan CV memiliki pergerakan yang relatif sama dengan tren yang cenderung menurun selama periode 20102014.

Berdasarkan hasil perhitungan, pada tahun 2010, infrastruktur panjang jalan provinsi di Indonesia memiliki nilai CV sebesar 2,17, meningkat menjadi 2,23 pada tahun 2011. Setelah melewati tahun 2011, nilai CV konsisten menurun hingga tahun 2014 yang tercatat sebesar 2,14. Sedikit berbeda dengan nilai CV yang memiliki dua fase pergerakan yang berlainan, nilai Indeks Williamson selama 2010-2014 konsisten menurun. Pada tahun 2010, nilai Indeks Williamson tercatat sebesar 0,78, sedikit menurun menjadi 0,77 pada tahun 2014. Rata-rata nilai Indeks Williamson pada periode tersebut tercatat lebih dari 0,7. Fakta ini mengindikasikan bahwa kesenjangan infrastruktur panjang jalan antarprovinsi di Indonesia masih relatif tinggi. Temuan ini menjelaskan bahwa untuk memperkecil kesenjangan panjang jalan pemerintah perlu memperluas pembangunan infrastruktur jalan di wilayah-wilayah yang masih relatif tertinggal. Valerio Mendoza (2017) menyatakan bahwa keberadaan infrastruktur berkaitan dengan ukuran ketimpangan pendapatan wilayah. Pada perspektif lain, Simon \& Natarajan (2017) menyatakan bahwa perlambatan penurunan ketimpangan infrastruktur digambarkan dengan pertumbuhan di sektor infrastruktur yang tidak seimbang antarwilayah, khususnya transportasi.

Selanjutnya, untuk mengetahui gambaran mengenai struktur pertumbuhan infrastruktur antarprovinsi di Indonesia tahun 2010-2015 digunakan analisis tipologi Klassen. Tabel 3, Tabel 4, dan Tabel 5 memperlihatkan bahwa provinsi di Indonesia dapat 


\section{Peran Pembangunan Infrastruktur terhadap Ketimpangan Ekonomi Antarwilayah di Indonesia}

diklasifikasikan menjadi empat kriteria. Kriteria pertama adalah daerah dengan infrastruktur lebih maju (dengan tingkat infrastruktur di atas rata-rata infrastruktur provinsi secara nasional) dan memiliki pertumbuhan infrastruktur lebih cepat (dengan tingkat pertumbuhan di atas rata-rata provinsi secara nasional) yang dikategorikan dalam Kuadran I. Kriteria kedua adalah daerah dengan infrastruktur relatif belum maju (dengan tingkat infrastruktur yang lebih rendah dari rata-rata provinsi secara nasional) yang dikategorikan dalam Kuadran II. Kriteria ketiga adalah daerah dengan infrastruktur yang relatif tertinggal karena memiliki tingkat infrastruktur dan tingkat pertumbuhan infrastruktur di bawah rata-rata provinsi secara nasional, yang dikategorikan dalam Kuadran III. Kriteria terakhir adalah daerah dengan infrastruktur lebih maju tetapi dianggap tertekan karena memiliki tingkat pertumbuhan infrastruktur di bawah rata-rata provinsi secara nasional, yang dikategorikan dalam Kuadran IV. Pembagian kriteria tersebut didasarkan pada nilai rata-rata pertumbuhan infrastruktur untuk garis vertikal dan rata-rata infrastruktur untuk garis horizontal. Pada kasus panjang jalan diperoleh nilai rata-rata panjang jalan per luas wilayah sebesar $0,518 \mathrm{~km} / \mathrm{km}^{2}$, dengan rata-rata tingkat pertumbuhan sebesar 2,17 persen. Pada kasus air bersih, diperoleh rata-rata jumlah pelanggan per kapita sebesar 0,044 dengan rata-rata tingkat pertumbuhan sebesar 4,31 persen. Sementara untuk luas irigasi, diperoleh rata-rata luas irigasi per jumlah daerah irigasi sebesar 205.503 ha, dengan rata-rata tingkat pertumbuhan 117,3 persen.

Tabel 3. Klasifikasi Pertumbuhan Panjang Jalan Per Luas Wilayah Provinsi di Indonesia Periode 20102014 Menurut Tipologi Klassen

\begin{tabular}{|c|c|c|}
\hline PDRB Per Kapita (y) & $\mathbf{Y}_{\mathbf{d i}}>\mathbf{y}_{\mathbf{d i}}$ & $\mathbf{Y}_{\mathrm{di}}<\mathbf{y}_{\mathbf{d i}}$ \\
\hline $\mathbf{R}_{\mathrm{di}}>\mathbf{r}_{\mathbf{n i}}$ & $\begin{array}{l}\text { Daerah lebih maju dan cepat } \\
\text { tumbuh (Kuadran I) } \\
\text { Sumatera Barat, Kepulauan } \\
\text { Riau, Sulawesi Utara }\end{array}$ & $\begin{array}{l}\text { Daerah belum maju tetapi } \\
\text { berkembang cepat (Kuadran II) } \\
\text { Nanggroe Aceh Darussalam, Riau, } \\
\text { Jambi, Bengkulu, Bangka Belitung, } \\
\text { Nusa Tenggara Timur, Kalimantan } \\
\text { Tengah, Kalimantan Selatan, } \\
\text { Kalimantan Timur, Gorontalo, } \\
\text { Sulawesi Barat, Maluku, Maluku } \\
\text { Utara, Papua Barat }\end{array}$ \\
\hline $\mathbf{R}_{\mathbf{d i}}<\mathbf{r}_{\mathbf{n i}}$ & $\begin{array}{l}\text { Daerah lebih maju tetapi } \\
\text { tertekan (Kuadran IV) } \\
\text { DKI Jakarta, Jawa Barat, } \\
\text { Jawa Tengah, Daerah } \\
\text { Istimewa Yogyakarta, Jawa } \\
\text { Timur, Banten, Bali, Sulawesi } \\
\text { Selatan }\end{array}$ & $\begin{array}{l}\text { Daerah relatif lebih tertinggal } \\
\text { (Kuadran III) } \\
\text { Sumatera Utara, Sumatera Selatan, } \\
\text { Lampung, Nusa Tenggara Barat, } \\
\text { Kalimantan Barat, Sulawesi } \\
\text { Tengah, Sulawesi Tenggara, Papua }\end{array}$ \\
\hline
\end{tabular}

Sumber: Analisis Penulis, 2018

Pada kasus panjang jalan, hasil analisis tipologi Klassen memperlihatkan bahwa provinsi di Indonesia cenderung berada pada Kuadran II dan Kuadran III. Dalam jangka panjang, provinsi yang terdapat pada Kuadran II diperkirakan akan memberikan dampak positif bagi pertumbuhan panjang jalan nasional karena akan mampu mengejar pertumbuhan panjang jalan provinsi-provinsi yang sudah maju (memiliki tingkat panjang jalan lebih tinggi dari rata-rata provinsi secara nasional) seperti yang terdapat pada Kuadran I. Sementara itu, provinsi yang terdapat pada Kuadran IV dianggap sebagai provinsi yang jenuh, karena meskipun memiliki tingkat panjang jalan yang relatif tinggi, namun pertumbuhannya cenderung lambat. Untuk provinsi yang terdapat pada Kuadran III, yaitu daerah relatif lebih tertinggal dari sisi pembangunan panjang jalan, jika tidak mengalami perubahan secara signifikan, diperkirakan akan berdampak negatif bagi pertumbuhan panjang jalan nasional 
karena akan menghambat pembangunan dan meningkatkan kesenjangan panjang jalan di antara provinsi di Indonesia.

Tabel 3 memperlihatkan bahwa kesenjangan panjang jalan antarprovinsi di Indonesia masih cukup tinggi. Namun demikian, kesenjangan tersebut diperkirakan akan cenderung menurun pada masa mendatang, atau mengalami konvergensi. Hal ini diperlihatkan oleh garis regresi atau garis tren yang memiliki slope negatif, yang menunjukkan korelasi negatif antara tingkat panjang jalan dan pertumbuhan panjang jalan di provinsi di Indonesia. Konvergensi ini diperkirakan terjadi karena provinsi-provinsi yang saat ini memiliki tingkat panjang jalan relatif rendah (di bawah rata-rata provinsi secara nasional) memiliki kecenderungan untuk tumbuh lebih cepat. Sebaliknya, provinsi-provinsi yang saat ini memiliki tingkat panjang jalan relatif tinggi (di atas rata-rata provinsi secara nasional) memiliki kecenderungan untuk tumbuh lebih lambat.

Tabel 4. Klasifikasi Pertumbuhan Jumlah Pelanggan Air Bersih Per Kapita Provinsi di Indonesia Periode 2010-2014 Menurut Tipologi Klassen

\begin{tabular}{|c|c|c|}
\hline $\begin{array}{c}\text { PDRB Per Kapita }(y) \\
\text { Laju Pertumbuhan }(\mathbf{r})\end{array}$ & $\mathbf{Y}_{\mathrm{di}}>\mathbf{y}_{\mathrm{di}}$ & $\mathbf{Y}_{\mathrm{di}}<\mathbf{y}_{\mathrm{di}}$ \\
\hline $\mathbf{R}_{\mathrm{di}}>\mathbf{r}_{\mathrm{ni}}$ & $\begin{array}{l}\text { Daerah lebih maju dan } \\
\text { cepat tumbuh (Kuadran I) } \\
\text { Sumatera Utara, Sumatera } \\
\text { Barat, Sumatera Selatan, } \\
\text { Kepulauan Riau, DKI } \\
\text { Jakarta, Kalimantan Timur }\end{array}$ & $\begin{array}{l}\text { Daerah belum maju tetapi } \\
\text { berkembang cepat (Kuadran II) } \\
\text { Nanggroe Aceh Darussalam, Jawa } \\
\text { Tengah, Nusa Tenggara Barat, Nusa } \\
\text { Tenggara Timur, Kalimantan Barat, } \\
\text { Sulawesi Selatan, Gorontalo, } \\
\text { Maluku, Maluku Utara, Papua }\end{array}$ \\
\hline $\mathbf{R}_{\mathrm{di}}<\mathbf{r}_{\mathrm{ni}}$ & $\begin{array}{l}\text { Daerah lebih maju tetapi } \\
\text { tertekan (Kuadran IV) } \\
\text { Bali, Kalimantan Tengah, } \\
\text { Kalimantan Selatan, } \\
\text { Sulawesi Utara, Sulawesi } \\
\text { Barat }\end{array}$ & $\begin{array}{l}\text { Daerah relatif lebih tertinggal } \\
\text { (Kuadran III) } \\
\text { Riau, Jambi, Bengkulu, Lampung, } \\
\text { Bangka Belitung, Jawa Barat, } \\
\text { Daerah Istimewa Yogyakarta, Jawa } \\
\text { Timur, Banten, Sulawesi Tengah, } \\
\text { Sulawesi Tenggara, Papua Barat }\end{array}$ \\
\hline
\end{tabular}

Sumber: Analisis Penulis, 2018

Seperti halnya kasus panjang jalan, hasil analisis tipologi Klassen untuk air bersih memperlihatkan bahwa provinsi di Indonesia cenderung berada pada Kuadran II dan Kuadran III (Tabel 4). Hasil ini menjelaskan bahwa dalam jangka panjang, provinsi yang berada pada Kuadran II akan memberikan dampak positif bagi pertumbuhan jumlah pelanggan air bersih nasional karena diperkirakan mampu mengejar pertumbuhan jumlah pelanggan air bersih provinsi-provinsi yang sudah maju seperti yang terdapat pada Kuadran I. Provinsi yang berada pada Kuadran III, yaitu daerah relatif lebih tertinggal dari sisi jumlah pelanggan air bersih, jika tidak mengalami perubahan secara signifikan, diperkirakan akan berdampak negatif bagi pertumbuhan jumlah pelanggan air bersih nasional karena akan menghambat pembangunan dan meningkatkan kesenjangan jumlah pelanggan air bersih di antara provinsi di Indonesia. Sementara itu, provinsi yang terdapat pada Kuadran IV dianggap sebagai provinsi yang jenuh dari sisi pertumbuhan jumlah pelanggan air bersih, karena meskipun memiliki jumlah pelanggan air bersih relatif tinggi, pertumbuhannya cenderung lambat. 
Tabel 5. Klasifikasi Pertumbuhan Luas Irigasi Provinsi di Indonesia Periode 2010-2014 Menurut Tipologi Klassen

\begin{tabular}{|c|c|c|}
\hline $\begin{array}{l}\text { PDRB Per Kapita (y) } \\
\text { Laju Pertumbuhan (r) }\end{array}$ & $Y_{d i}>y_{d i}$ & $\mathbf{Y}_{\mathbf{d i}}<\mathbf{y}_{\mathbf{d i}}$ \\
\hline $\mathbf{R}_{\mathrm{di}}>\mathbf{r}_{\mathbf{n i}}$ & $\begin{array}{l}\text { Daerah lebih maju dan } \\
\text { cepat tumbuh (Kuadran I) } \\
\text { Sumatera Selatan, Lampung, } \\
\text { Kalimantan Tengah, } \\
\text { Kalimantan Selatan, } \\
\text { Sulawesi Selatan }\end{array}$ & $\begin{array}{l}\text { Daerah belum maju tetapi } \\
\text { berkembang cepat (Kuadran II) } \\
\text { Jambi, Bangka Belitung, } \\
\text { Kalimantan Barat, Sulawesi } \\
\text { Tenggara, Papua }\end{array}$ \\
\hline $\mathbf{R}_{\mathbf{d i}}<\mathbf{r}_{\mathbf{n i}}$ & $\begin{array}{l}\text { Daerah lebih maju tetapi } \\
\text { tertekan (Kuadran IV) } \\
\text { Nanggroe Aceh Darussalam, } \\
\text { Sumatera Utara, Sumatera } \\
\text { Barat, Jawa Barat, Jawa } \\
\text { Tengah, Jawa Timur, } \\
\text { Nusa Tenggara Barat, } \\
\text { Nusa Tenggara Timur }\end{array}$ & $\begin{array}{l}\text { Daerah relatif lebih tertinggal } \\
\text { (Kuadran III) } \\
\text { Riau, Bengkulu, Kepulauan Riau, } \\
\text { DKI Jakarta, Daerah Istimewa } \\
\text { Yogyakarta, Banten, Bali, } \\
\text { Kalimantan Timur, Sulawesi Utara, } \\
\text { Sulawesi Tengah, Gorontalo, } \\
\text { Sulawesi Barat, Maluku, Maluku } \\
\text { Utara, Papua Barat }\end{array}$ \\
\hline
\end{tabular}

Sumber: Analisis Penulis, 2018

Berdasarkan hasil kategorisasi tipologi Klassen pada jumlah pelanggan air bersih, kesenjangan jumlah pelanggan air bersih antarprovinsi di Indonesia masih cukup tinggi. Namun demikian, kesenjangan tersebut diperkirakan akan menurun pada masa mendatang, atau mengalami konvergensi. Hal ini ditunjukkan oleh garis regresi atau garis tren yang memiliki slope negatif, yang berarti adanya korelasi negatif antara jumlah pelanggan air bersih dengan pertumbuhannya di provinsi di Indonesia. Konvergensi ini diperkirakan terjadi karena provinsi-provinsi yang saat ini memiliki jumlah pelanggan air bersih relatif rendah, namun memiliki kecenderungan untuk tumbuh lebih cepat. Sebaliknya, provinsi-provinsi yang saat ini memiliki jumlah pelanggan air bersih relatif tinggi mempunyai kecenderungan untuk tumbuh lebih lambat.

Tabel 5 memperlihatkan bahwa provinsi di Indonesia cenderung berada pada Kuadran I, Kuadran III dan Kuadran IV. Hal tersebut menunjukkan bahwa terdapat beberapa provinsi yang telah memiliki luas irigasi relatif baik dan berada pada Kuadran I. Selanjutnya, provinsi pada Kuadran III, yaitu daerah relatif lebih tertinggal dari sisi luas irigasi, jika tidak mengalami perubahan secara signifikan, maka diperkirakan berdampak negatif terhadap pertumbuhan luas irigasi nasional. Hal ini karena bisa menghambat pembangunan dan meningkatkan kesenjangan luas irigasi antarprovinsi di Indonesia. Sementara itu, provinsi pada Kuadran IV dianggap sebagai provinsi yang jenuh dari sisi pertumbuhan luas irigasi, karena meskipun memiliki tingkat luasan irigasi relatif tinggi, namun pertumbuhannya cenderung lambat.

\section{Keterkaitan Kesenjangan Infrastruktur dan Ekonomi}

Pembangunan infrastruktur merupakan salah satu aspek penting dan vital untuk mempercepat proses pembangunan nasional. Infrastruktur memegang peranan penting dan strategis dalam menggerakkan roda perekonomian. Gerak laju dan pertumbuhan ekonomi suatu negara tidak dapat dipisahkan dari ketersediaan infrastruktur seperti jalan, transportasi, telekomunikasi, sanitasi, dan energi. Dalam hal ini, pembangunan sektor infrastruktur menjadi salah satu fondasi dari pembangunan ekonomi ke depan. Beberapa studi menyebutkan bahwa keberadaan infrastruktur memiliki keterkaitan yang erat dengan tingkat perkembangan suatu wilayah, yang dicirikan oleh laju pertumbuhan ekonomi dan 
kesejahteraan masyarakat (Calderón \& Servén, 2004, 2014; Charlery et al., 2016; Chatterjee \& Turnovsky, 2012; Démurger, 2001; Maryaningsih et al., 2014; Umiyati, 2012). Sejalan dengan studi-studi tersebut di atas, hasil penelitian berdasarkan komparasi antara Tabel 3, Tabel 4 dan Gambar 3 menunjukkan bahwa daerah yang mempunyai kelengkapan sistem infrastruktur yang lebih baik, cenderung mempunyai tingkat laju pertumbuhan ekonomi dan kesejahteraan masyarakat yang lebih baik pula dibandingkan dengan daerah yang mempunyai kelengkapan infrastruktur yang terbatas.

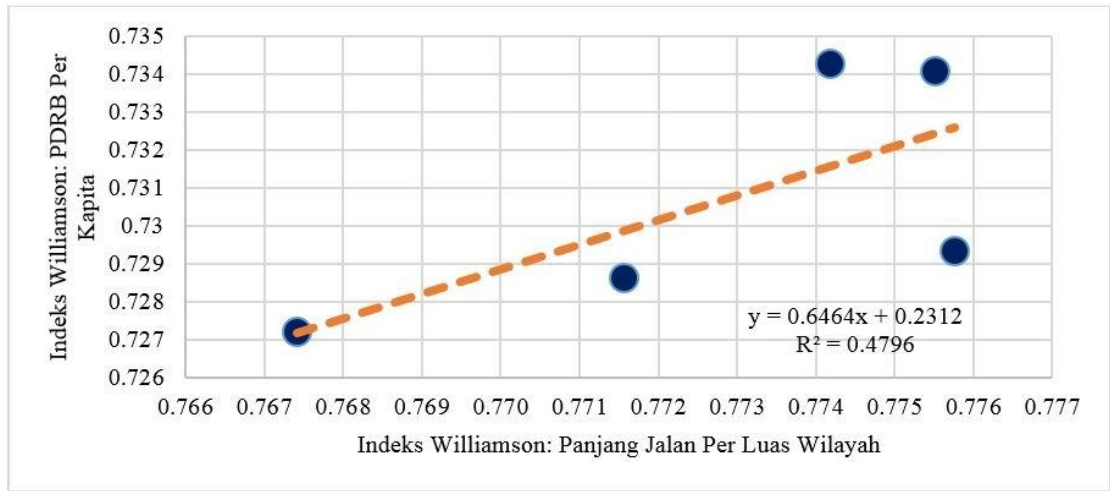

(a)

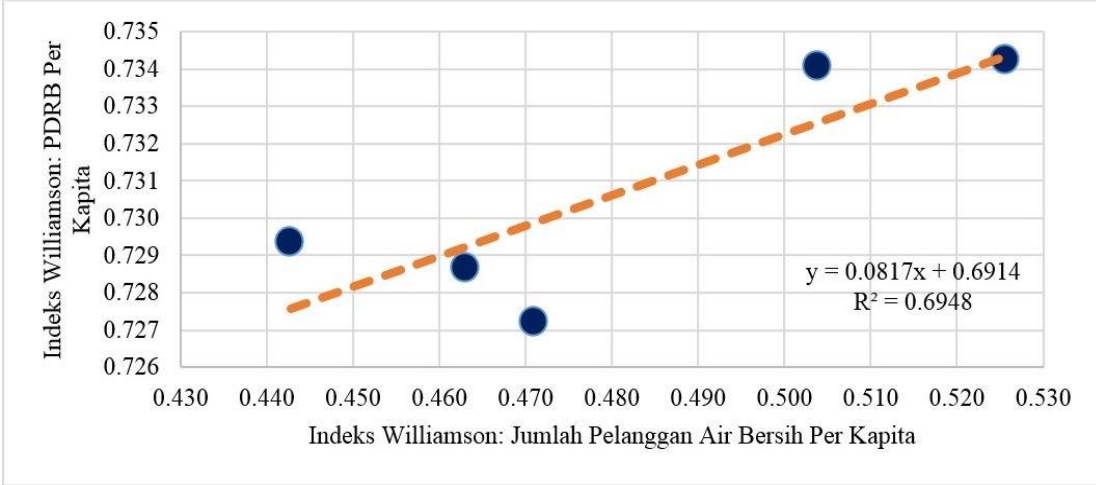

(b)

Keterangan:

(a) Scatter Plot Indeks Williamson: PDRB Per Kapita vs. Panjang Jalan Per Luas Wilayah

(b) Scatter Plot Indeks Williamson: PDRB Per Kapita vs. Jumlah Pelanggan Air Bersih Per Kapita

Sumber: Analisis Penulis, 2018

\section{Gambar 3. Scatter Plot Indeks Williamson}

Bagian ini secara khusus menganalisis keterkaitan antara kesenjangan infrastruktur, yaitu: panjang jalan, (jumlah pelanggan) air bersih, dan luasan irigasi dengan kesenjangan ekonomi (PDRB per kapita) di antara provinsi-provinsi di Indonesia. Hasil korelasi di antara kedua indikator tersebut digambarkan melalui diagram scatter plot untuk kesenjangan panjang jalan dan jumlah pelanggan air bersih dengan kesenjangan ekonomi antarprovinsi di Indonesia (lihat Gambar 3a dan Gambar 3b). Hasil korelasi tersebut memperlihatkan adanya asosiasi atau hubungan positif di antara kedua indikator tersebut. Dalam hal ini, semakin tinggi kesenjangan infrastruktur panjang jalan dan jumlah pelanggan air bersih cenderung diikuti oleh semakin tinggi kesenjangan ekonomi (PDRB per kapita), begitupun sebaliknya. Menurut Bajar \& Rajeev (2016), komponen infrastruktur, terutama listrik dan jalan, cenderung meningkatkan kesenjangan di tingkat regional. Sementara itu Makmuri (2017) menemukan bahwa ketidakseimbangan jumlah infrastruktur jalan dan telekomunikasi cenderung meningkatkan ketimpangan pendapatan antarwilayah di Indonesia. Penelitian 
Prasetyo et al, (2013) menunjukkan bahwa infrastruktur memiliki hubungan tidak langsung dengan ketimpangan pendapatan melalui pendapatan per kapita. Fakta ini sesuai dengan hasil penelitian ini yang menjelaskan bahwa pembangunan infrastruktur provinsi di Indonesia seperti irigasi, jalan, dan air bersih berkaitan erat dengan perkembangan ekonomi yang terjadi pada provinsi tersebut.

\section{Kesimpulan}

Studi ini menemukan adanya kesenjangan ekonomi (PDRB per kapita) antarprovinsi di Indonesia selama periode 2011-2015, yang diperlihatkan oleh angka Indeks Williamson sebesar 0,7. Kesenjangan tersebut utamanya diasosiasikan dengan perbedaan penyerapan investasi dan kesenjangan infrastruktur yang ada. Hasil ini sejalan dengan temuan Mahardiki \& Santoso (2013), bahwa rata-rata ketimpangan PDRB per kapita antarprovinsi di Indonesia selama periode 2006-2011 mencapai nilai 0,796. Hasil ini juga sejalan dengan analisis Tipologi Klassen yang memperlihatkan kesenjangan pendapatan (PDRB per kapita) antarprovinsi di Indonesia masih relatif tinggi. Konvergensi ini diperkirakan terjadi karena provinsi-provinsi yang saat ini memiliki tingkat PDRB per kapita relatif rendah, memiliki kecenderungan untuk tumbuh lebih cepat. Sebaliknya, provinsi-provinsi yang saat ini memiliki tingkat PDRB per kapita relatif tinggi, memiliki kecenderungan untuk tumbuh lebih lambat. Hasil-hasil penelitian terdahulu menunjukkan juga bahwa ketimpangan pertumbuhan ekonomi antarwilayah yang tinggi banyak ditemukan di daerah pada kategori daerah maju tapi tertekan dan daerah tertinggal yang menghadapi masalah sosial ekonomi seperti kemiskinan, pengangguran, dan lapangan usaha (Hermayeni et al., 2015; Mahardiki \& Santoso, 2013; Umiyati, 2013).

Tren kesenjangan infrastruktur (panjang jalan, jumlah pelanggan air bersih, dan luasan irigasi) selama 2010-2014 cukup bervariasi. Namun demikian, tingkat kesenjangan pada tingkat pemerataan jumlah pelanggan air bersih masih relatif lebih rendah jika dibandingkan dengan tingkat kesenjangan pada kasus panjang jalan provinsi di Indonesia pada periode yang sama. Hasil studi menemukan adanya hubungan positif antara kesenjangan infrastruktur dan kesenjangan ekonomi pada periode 2013-2014. Kondisi tersebut menunjukkan bahwa kesenjangan infrastruktur panjang jalan dan jumlah pelanggan air bersih cenderung diikuti oleh kesenjangan ekonomi (PDRB per kapita).

Peranan infrastruktur sebagai penggerak di sektor perekonomian akan mampu menjadi pendorong berkembangnya sektor-sektor terkait sebagai efek pengganda dan pada akhirnya akan menciptakan lapangan usaha baru dan memberikan output hasil produksi sebagai input untuk konsumsi. Oleh karena itu, pemerintah perlu mengakselerasi programprogram pemerataan pembangunan secara proposional di seluruh wilayah. Dengan demikian, proses pembangunan yang terjadi tidak hanya bias pada wilayah yang sudah maju saja, tetapi juga pada wilayah-wilayah lainnya yang dianggap masih tertinggal. Infrastruktur diyakini dapat mengakselerasi pembangunan ekonomi nasional dan memperbaiki tingkat kesenjangan ekonomi antarwilayah. Dalam konteks ini, pembangunan infrastruktur dapat menjadi pendorong pertumbuhan ekonomi. Di lain sisi, berbagai tantangan dalam pengelolaan dan pengembangan infrastruktur cukup banyak, seperti terdapat kesenjangan infrastruktur antarwilayah dan belum optimalnya jaringan infrastruktur untuk mendukung keberlanjutan pembangunan ekonomi di masa mendatang. Oleh karena itu, sebagai penunjang kesejahteraan masyarakat dan investasi pembangunan diperlukan berbagai infrastruktur, antara lain jaringan jalan, jaringan listrik, jaringan telekomunikasi, air bersih, dan sebagainya. Dorongan peningkatan pada infrastruktur tersebut disebabkan karena tingkat permintaan dari subsektor tersebut terus mengalami peningkatan. Hal ini dapat dipahami karena kebutuhan terhadap infrastruktur akan terus meningkat seiring terus berlangsungnya proses pembangunan. Menurut Ghosh (2017), pentingnya berbagai infrastruktur menunjukkan bahwa pemerintah harus memprioritaskan investasi tambahan 
pada listrik, jalan, irigasi, perumahan dan telekomunikasi untuk meningkatkan kesejahteraan secara keseluruhan. Investasi publik menghasilkan korelasi positif antara pertumbuhan dan ketimpangan pendapatan (Chatterjee \& Turnovsky, 2012).

\section{Daftar Pustaka}

Aswandi, H., \& Kuncoro, M. (2002). Evaluasi penetapan kawasan andalan: Studi empris di Kalimantan Selatan 1993-1999. Jurnal Ekonomi Dan Bisnis Indonesia, 171), 27-45. doi:10.22146/jieb.6703.

Bajar, S., \& Rajeev, M. (2016). The impact of infrastructure provisioning on inequality in India: Does the level of development matter? Journal of Comparative Asian Development, 15(1), 122-155. doi:10.1080/15339114.2016.1150188.

Badan Pusat Statistik (BPS). (2018). Jumlah Penduduk Miskin, Persentase Penduduk Miskin dan Garis Kemiskinan, 1970-2017. Badan Pusat Statistik. Retrieved from https://www.bps.go.id/statictable/2014/01/30/1494/jumlah-penduduk-miskin--persentasependuduk-miskin-dan-garis-kemiskinan--1970-2017.html.

Bhinadi, A. (2003). Disparitas pertumbuhan ekonomi Jawa dengan Luar Jawa. Jurnal Ekonomi Pembangunan, 8(1), 39-48. Retrieved from http://journal.uii.ac.id/JEP/article/view/638.

Calderón, C., \& Servén, L. (2004). The effects of infrastructure development on growth and income distribution (Working Papers No. 3400). Working Papers No. 3400. doi:10.1596/1813-9450-3400.

Calderón, C., \& Servén, L. (2014). Infrastructure, growth, and inequality: An overview (Policy Research Working Paper No. 7034). Retrieved from https://openknowledge.worldbank.org/handle/10986/20365.

Charlery, L. C., Qaim, M., \& Smith-Hall, C. (2016). Impact of infrastructure on rural household income and inequality in Nepal. Journal of Development Effectiveness, 8(2), 266-286. doi:10.1080/19439342.2015.1079794.

Chatterjee, S., \& Turnovsky, S. J. (2012). Infrastructure and inequality. European Economic Review, 56(8), 17301745. doi:10.1016/j.euroecorev.2012.08.003.

Chotia, V., \& Rao, N. V. . (2017). Investigating the interlinkages between infrastructure development, poverty and rural-urban income inequality: Evidence from Brics Nations. Studies in Economics and Finance, 34(4), 466484. doi:10.1108/SEF-07-2016-0159.

Démurger, S. (2001). Infrastructure development and economic growth: An explanation for regional disparities in China? Journal of Comparative Economics, 29(1), 95-117. doi:10.1006/jcec.2000.1693.

Fahmi, A. (2015). Pengaruh infrastruktur dan keterkaitan spasial terhadap konvergensi beta di Indonesia. Jurnal Ekonomi Pembangunan, 13(1), 87-105. Retrieved from http://ejournal.umm.ac.id/index.php/jep/article/view/3694.

Fan, S., \& Chan-Kang, C. (2008). Regional road development, rural and urban poverty: Evidence from China. Transport Policy, 15(5), 305-314. doi:10.1016/j.tranpol.2008.12.012.

Ghosh, M. (2017). Infrastructure and development in rural India. Margin: The Journal of Applied Economic Research, 11(3), 256-289. doi:10.1177/0973801017703499.

Gibson, J., \& Rioja, F. (2014). A bridge to equality: How investing in infrastructure affects the distribution of wealth. $\quad$ Retrieved from https://www.frbatlanta.org//media/documents/news/conferences/2014/SIDE-workshop/papers/Gibson-Rioja.pdf.

Hermayeni, S., Ekwarso, H., \& Tampubolon, D. (2015). Analisis ketimpangan investasi antar provinsi di Pulau Sumatera dan Kalimantan Tahun 2005-2013. Jurnal Online Mahasiswa Fakultas Ekonomi Universitas Riau, 2(1), 1-10. Retrieved from https://jom.unri.ac.id/index.php/JOMFEKON/article/view/7887/0.

Kateja, A., \& Maurya, N. (2011). Inequality in infrastructure and economic development: Interrelationship reexamined. The Indian Economic Journal, 58(4), 111-127. doi:10.1177/0019466220110407.

Madhu Sehrawat, A. K. G. (2016). Panel data analysis of financial development, economic growth and rural-urban income inequality: Evidence from SAARC countries. International Journal of Social Economics, 43(10), 998-1015. doi:10.1108/IJSE-10-2014-0211.

Mahardiki, D., \& Santoso, R. P. (2013). Analisis perubahan ketimpangan pendapatan dan pertumbuhan ekonomi antar propinsi di Indonesia 2006-2011. JEJAK Journal of Economics and Policy, 6(2), 103-213. doi:10.15294/jejak.v7i1.3596. 


\section{Peran Pembangunan Infrastruktur terhadap Ketimpangan Ekonomi Antarwilayah di Indonesia}

Majumder, R. (2012). Removing poverty and inequality in India: The role of infrastructure (MPRA Paper No. 40941). Munich Personal RePEc Archive. Retrieved from https://mpra.ub.unimuenchen.de/40941/1/rm24.pdf.

Makmuri, A. (2017). Infrastructure and inequality: An empirical evidence from Indonesia. Economic Journal of Emerging Markets, 9(1), 29-39. doi:10.20885/ejem.vol9.iss1.art4.

Maryaningsih, N., Hermansyah, O., \& Savitri, M. (2014). Pengaruh infrastruktur terhadap pertumbuhan ekonomi IndonesIa. Buletin Ekonomi Moneter Dan Perbankan, 1711), 61-98. doi:10.21098/bemp.v17i1.44.

Muljono, S., Antameng, M., Sinaga, B. M., \& Daryanto, A. (2010). Dampak pembangunan jalan terhadap pendapatan faktor produksi intra dan inter regional KBI-KTI. Jurnal Transportasi, 10(2), 99-110. Retrieved from http://journal.unpar.ac.id/index.php/journaltransportasi/article/view/385.

Østby, G. (2016). Rural-urban migration, inequality and urban social disorder: Evidence from African and Asian cities. Conflict Management and Peace Science, 33(5), 491-515. doi:10.1177/0738894215581315.

Prasetyo, B. A., Priyarsono, D. S., \& Mulatsih, S. (2013). Infrastructure, economic growth and inequality in Indonesia Land Borders. Economic Journal of Emerging Markets, 5(2), 99-108. doi:10.20885/ejem.vol5.iss2.art3.

Rosmeli. (2015). Dampak investasi dan tenaga kerja terhadap ketimpangan pembangunan kawasan timur indonesia. Jurnal Paradigma Ekonomika, 19(2), 362-369. Retrieved from https://onlinejournal.unja.ac.id/index.php/paradigma/article/view/3681.

Simon, N. S., \& Natarajan, P. (2017). Nonlinearity between infrastructure inequality and growth: Evidence from India. Review of Market Integration, 9(1-2), 66-82. doi:10.1177/0974929217721764.

Siregar, H., \& Sukwika, T. (2007). Faktor-faktor yang mempengaruhi kinerja pasar tenaga kerja dan implikasi kebijakannya terhadap sektor pertanian di Kabupaten Bogor. SOCA (Socio-Economic of Agriculture and Agribusiness), 73), 1-22. Retrieved from https://ojs.unud.ac.id/index.php/soca/article/view/4216.

Sumadiasa, I. K., Trisnawati, N. M., \& Wirathi, I. G. A. P. (2016). Analisis pengaruh pembangunan infrastruktur jalan, listrik, dan PMA terhadap pertumbuhan PDRB Provinsi Bali Tahun 1993-2014. E-Jurnal Ekonomi Pembangunan Universitas Udayana, 5(7), 925-947. Retrieved from https://ojs.unud.ac.id/index.php/eep/article/view/22964.

Surd, V., Kassai, I., \& Giurgiu, L. (2011). Romania disparities in regional development. In Procedia - Social and Behavioral Sciences (Vol. 19, pp. 21-30). Elsevier B.V. doi:10.1016/j.sbspro.2011.05.102.

Umiyati, E. (2012). Analisis tipologi pertumbuhan ekonomi dan disparitas pendapatan dalam implementasi otonomi daerah di Propinsi Jambi. Jurnal Paradigma Eonomika, 1(5), 15-21. Retrieved from https://online-journal.unja.ac.id/index.php/paradigma/article/view/549.

Umiyati, E. (2013). Analisa pertumbuhan ekonomi dan ketimpangan pembangunan antar wilayah di Pulau Sumatera. Jurnal Paradigma Ekonomika, 1(7), 42-50. Retrieved from https://onlinejournal.unja.ac.id/index.php/paradigma/article/view/2207.

Valerio Mendoza, O. (2017). Infrastructure development, income inequality and urban sustainability in the People's Republic of China (ADBI Working Paper 713). Tokyo.

Warr, P., Menon, J., \& Rasphone, S. (2015). Public services and the poor in Laos. World Development, 66, 371382. doi:10.1016/j.worlddev.2014.08.015.

Williamson, J. G. (1965). Regional inequality and the process of national development: A description of the patterns. Economic Development and Cultural Change, 13(4), 1-84. doi:10.1086/450136.

Yuliadi, I. (2012). Kesenjangan investasi dan evaluasi kebijakan pemekaran wilayah di indonesia. Jurnal Ekonomi $\begin{array}{llll}\text { Pembangunan, } & 13(2), & \text { 276-287. } & \text { Retrieved }\end{array}$ http://journals.ums.ac.id/index.php/JEP/article/view/174/161. 